\title{
DIVERSITY IN MAIN DISHES PREVENTS CHILDREN FROM COMPOSITE INDEX OF ANTHROPOMETRIC FAILURE (CIAF)
}

\author{
Welly Femelia ${ }^{1}$, Sukarsi Rusti ${ }^{2}$, Zainal Abidin ${ }^{3}$ \\ Magister Ilmu Kesehatan Masyarakat, STIKes Fort De Kock Bukittinggi 1,2,3 \\ email:ㄹ.w3ll@gmail.com ${ }^{1}, \underline{\text { rustiuci@gmail.com }}^{2}$
}

Submitted: 28-11-2018, Reviewer: 02-01-2019, Accepted: 10-04-2019

\begin{abstract}
Background: Malnutrition that occurs in early period of life caused the vulnerable to diseases, cognitive disorder and failed to thrive. Failed to thrive decide from the result of anthropometric measurement. Failed to thrive happened when the result of measuring indicate a problem. If the problem showed in two or more index, it is called CIAF. In Indonesia one of two children had CIAF $(51,4 \%)$. Cities in Indonesia use only a single index of anthropometry so the data of CIAF is not available. Objective: the objective of the study was to find the association of food diversity with the incidence of CIAF. Method: cross - sectional design applied in this study with the number of sample were 267 children aged 2 - 5 years. Result: there were 23,6\% children suffered from CIAF and generally consume the same type of food everyday. There was a significant association between diversity in main food consumption with the incidence of CIAF $(p=0,034)$. It means children who consume diversity main food everyday protected from CIAF compared to the children who eat the same main food each day $(O R=2)$. Conclusion: main food diversity prevents the children from CIAF. The mother expected to provide diversity source for the main dishes everyday (other than rice) such as bread or potato. For the health institutions, suggested to increase the education about the variaty of food processing towards so that the children could escape from the boredom.
\end{abstract}

Keywords: CIAF, food diversity, nutrition

\begin{abstract}
ABSTRAK
Latar Belakang: Malnutrisi yang terjadi pada masa awal kehidupan mengakibatkan anak rentan terhadap penyakit, gangguan kognisi dan gagal tumbuh. Gagal tumbuh dapat dilihat dari hasil pengukuran antropometri pada anak. Anak dinyatakan gagal tumbuh jika hasil pengukuran pada salah satu indeks antropometri bermasalah. Hasil pengukuran yang bermasalah pada lebih dari satu indeks antropometri dianggap sebagai kegagalan antropometri gabungan/Composite Indeks of Anhtropometric Failure (CIAF)di Indonesia satu dari dua anak mengalami CIAF (51,4\%). Di kota Bukittinggi belum dilakukan pengukuran yang sama sehingga data yang tersedia hanya data konvensional (dengan analisis satu indeks antropometri). Tujuan: Tujuan dari penelitian ini adalah mengetahui hubungan keragaman makanan balita dengan kejadian kegagalan antropometri gabungan (CIAF). Metode: penelitian ini menggunakan desain potong - lintang dengan jumlah sampel 267 balita berusia 2 - 5 tahun. Hasil: terdapat 23,6\% balita mengalami CIAF dan sebagian besar tidak mengonsumsi makanan pokok, sumber protein, sayur dan buah serta makanan pendukung pertumbuhan secara beragam. Analisis lebih lanjut menunjukkan bahwa terdapat hubungan yang signifikan $(p=0,034)$ antara konsumsi makanan pokok beragam dengan kejadian CIAF. Balita yang mengonsumsi makanan pokok beragam terlindungi dari CIAF sebesar 1,9 kali. Kesimpulan: mengonsumsi makanan pokok yang bervariasi dapat melindungi anak dari CIAF. Diharapkan kepada ibu agar memvariasikan makanan harian anak (selain nasi) dengan roti atau kentang. Kepada instansi kesehatan diharapkan agar meningkatkan edukasi tentang cara mengolah makanan anak sehingga menu yang bervariasi dapat menghindarkan anak dari kebosanan.
\end{abstract}

Kata Kunci:CIAF, gizi, keragaman makanan 


\section{PENDAHULUAN}

Malnutrisi dengan segala bentuknya adalah kontributor utama dalam kesakitan dan kematian dini pada ibu dan bayi. Gizi kurang bisa mengarah kepada masalah kesehatan lintas generasi, khususnya pada populasi rentan (WHO, 2012). Malnutrisi yang terjadi dalam kandungan dan masa awal menyebabkan janin melakukan penyesuaian. Secara paralel, penyesuaian tersebut meliputi perlambatan pertumbuhan dengan pengurangan jumlah dan pengembangan sel - sel tubuh termasuk sel otak dan organ lainnya. Hasil penyesuaian ini pada usia dewasa dapat berupa tubuh yang pendek, rendahnya kemampuan kognitif dan peningkatan risiko terjadinya penyakit tidak menular (Bappenas, 2012).

Tubuh yang pendek pada usia dewasa, terutama pada perempuan akan cenderung melahirkan anak - anak yang pendek. Keadaan ini akan berulang sehingga terjadilah masalah gizi inter - generasi. Sedangkan bertubuh gemuk akan berisiko terhadap penyakit - penyakit tidak menular (Bappenas, 2012).

Tujuan Sustainable Development Goals (SDG's) yang kedua yaitu mengakhiri kelaparan, mencapai ketahanan pangan dan meningkatkan gizi serta medorong pertanian yang berkelanjutan. Untuk mencapai tujuan ini perlu dilakukan upaya memenuhi delapan target, salah satunya adalah mengakhiri segala bentuk malnutrisi. Oleh karena itu pemerintah merencanakan berbagai upaya terkait dengan peningkatan status gizi.

WHO merekomendasikan penggunaan Z-skor untuk menganalisa data antropometri di negara berpendapatan rendah (Gibson, 2005). Di Indonesia pengukuran status gizi secara antropometri dilakukan dengan menggunakan indeks BB/U, TB/U dan BB/TB (Kepmenkes RI, 2010). Kegagalan antropometri gabungan Composite Index of Anthropometric Failure (CIAF) merupakan kondisi gangguan gizi yang bermasalah pada lebih dari satu indeks antropometri. Untuk hasil pengukuran CIAF digunakan penggabungan dari ketiga indeks tersebut sehingga akan dihasilkan status gizi anak pendek - gemuk, pendek - kurus, TB normal - kurus, dan TB normal - gemuk (Kemenkes RI, 2013).

Pada anak dengan CIAF terjadi peningkatan resiko terhadap kematian jika dibandingkan dengan anak yang normal. Anak yang pendek dan kurang gizi tetapi tidak kurus berisiko 3,4 kali lebih besar sedangkan anak yang kurus dan kurang gizi tetapi tidak pendek berisiko 4,7 kali lebih besar. Resiko paling tinggi terhadap kematian $(12,3)$ terjadi pada anak yang pendek - kurang gizi - kurus (Mc Donald et al, 2013).

CIAF umumnya terjadi di negara yang sedang berkembang dan hampir tidak ditemukan di negara maju. Di Etiopia ditemukan kejadian multiple anthropometric - failure sebesar 44,63\% (Fentahun et al, 2016). Sedangkan di negara India prevalensinya lebih rendah yaitu $36 \%$ (Dasgupta, et al, 2014) dan 31,8\% (Savanur\&Ghugre, 2015).

Secara nasional, angka masalah gizi gabungan pada balita adalah pendek - kurus $2,5 \%$,

pendek - normal 27, 4\%, pendek gemuk $6,8 \%$, normal - kurus 9,6\%, dan normal - gemuk 5,1\% (Riskesdas, 2013). Jika dijumlahkan maka diperoleh angka $51,4 \%$ jumlah balita yang mengalami kegagalan antropometri gabungan atau CIAF. Dengan demikian, hanya $48,6 \%$ balita di Indonesia yang terbebas dari masalah gizi.

Survey Diet Total tahun 2014 menunjukkan bahwa sebagian besar penduduk di Indonesia memiliki tingkat kecukupan energi sangat kurang $(45,7 \%)$ dan kurang $(33,9 \%)$. Provinsi Sumatera Barat berada pada posisi yang tidak jauh dari angka nasional yaitu $41 \%$ (sangat kurang) dan $39 \%$ (kurang). Sedangkan untuk anak usia balita, rata - rata asupan energi adalah 1137 kkal (dianjurkan 1118 kkal). Provinsi Sumatera Barat termasuk salah satu provinsi dengan Angka 
Kecukupan Energi (AKE) pada balita tergolong sangat kurang.

Fentahun et al (2016) melakukan penelitian pada masyarakat petani kopi di Etiopia dengan desain penelitian kohort. Hasil penelitian menunjukkan bahwa kejadian CIAF dipengaruhi oleh jenis kelamin anak $(\mathrm{OR}=7,4)$, keanekaragaman makanan yang rendah $(\mathrm{OR}=3,1)$, keanekaragaman makanan sedang $(\mathrm{OR}=$ 1,9) dan ketiadaan makanan khusus ketika anak sakit $(\mathrm{OR}=1,8)$. Keempat variabel ini berhubungan siginifikan pada $\mathrm{p}<0,001$ dan $\mathrm{p}<0,05$.

Tidak hanya Fentahun, Abate dan Belachew (2017) juga melakukan penelitian tentang status gizi di negara yang sama menggunakan desain cross - sectional. Mereka menemukan bahwa prevalensi stunting adalah $19,7 \%$ dan wasting sebesar $8,8 \%$. Sedangkan faktor yang mempengaruhinya adalah jenis kelamin anak (untuk wasting dan stunting), otonomi ibu (untuk wasting saja) dan keterlibatan ayah dalam pengasuhan (stunting saja).

Penelitian ini bertujuan untuk melihat hubungan antara keragaman makanan pada anak dengan kejadian CIAF. Sampai saat ini sebagian besar penelitian serupa hanya menggunakan data sekunder yang diambil dari survey nasional suatu wilayah. Dalam penelitian ini akan digunakan data primer yang diperoleh melalui observasi (pengukuran status gizi anak) dan wawancara (keragaman makanan anak).

\section{METODE}

Penelitian ini dilakukan di enam puskesmas di wilayah kerja Dinas Kesehatan Kota Bukittinggi. Desain yang digunakan dalam penelitian ini adalah cross-sectional (potong - lintang). Data pada masing-masing variabeldikumpulkan selama bulan April - Juni 2018. Populasi penelitian adalah balita berusia $2-5$ tahun yang berjumlah 3510 orang sedangkan sampel berjumlah 267 orang balita. Pengambilan sampel dilakukan secara proporsional random sampling, dengan kriteria: mampu berdiri dan sudah disapih (tidak disusui). Instrumen yang digunakan dalam penelitian ini adalah timbangan injak, mikrotoise dan Food Frequency Questionnaire (FFQ). Timbangan digunakan untuk mengukur berat badan anak dengan ketelitian hasil pengukuran 0,1 kilogram.Mikrotoise digunakan untuk mengukur tinggi badan anak dengan ketelitian hasil pengukuran 1 sentimeter. Kedua hasil pengukuran ini dikonversi menjadi $\mathrm{Z}$ - skor dengan menggunakan software WHO - anthro 2009 untuk mendapatkan kategori status gizi anak. FFQ digunakan untuk melihat variasi makanan yang dikonsumsi oleh anak. Di dalam FFQ terdapat daftar makanan yang biasa dikonsumsi anak - anak di Kota Bukittinggi.Hasil pengukuran terhadap kedua variabel tersebut dianalisis secara univariat dan bivariat.

\section{HASIL DAN PEMBAHASAN}

Jumlah sampel dalam penelitian ini adalah 267 orang anak beserta ibunya. Berikut ini adalah karakteristik masing masing kelompok sampel (tabel 1).

Tabel 1

Karakteristik Responden

\begin{tabular}{|c|c|c|}
\hline Karakteristik Ibu & $\mathbf{n}$ & $\%$ \\
\hline \multicolumn{3}{|l|}{ Umur } \\
\hline$-\leq 30$ tahun & 117 & 43,8 \\
\hline$->30$ tahun & 150 & 56,2 \\
\hline \multicolumn{3}{|l|}{ Pendidikan Ibu } \\
\hline - Rendah & 63 & 23,6 \\
\hline - Tinggi & 204 & 76,4 \\
\hline \multicolumn{3}{|l|}{ Pekerjaan } \\
\hline - Formal & 39 & 14,6 \\
\hline - Informal & 29 & 10,9 \\
\hline - Tidak Bekerja & 199 & 74,5 \\
\hline Karakteristik Balita & $\mathbf{n}$ & $\%$ \\
\hline \multicolumn{3}{|l|}{ Jenis Kelamin } \\
\hline - Laki - laki & 146 & 54,7 \\
\hline - Perempuan & 121 & 45,3 \\
\hline \multicolumn{3}{|l|}{ Umur } \\
\hline$-\leq 36$ bulan & 113 & 42,3 \\
\hline - $37-48$ bulan & 86 & 32,2 \\
\hline$-\geq 59$ bulan & 68 & 25,5 \\
\hline \multicolumn{3}{|l|}{ Urutan lahir } \\
\hline$-\leq 2$ & 192 & 71,9 \\
\hline$->2$ & 75 & 28,1 \\
\hline
\end{tabular}


Berdasarkan tabel diatas dapat disimpulkan bahwa sebagian besar ibu balita masih berusia muda dan berpendidikan tinggidan tidak memiliki pekerjaan (ibu rumah tangga). Dapat diketahui pula bahwa sebagian besar anak berjenis kelamin laki - laki dan merupakan batita (bawah tiga tahun).Umumnya anak anak ini merupakan anak pertama atau kedua didalam keluarganya.

Kegagalan antropometri gabungan atau CIAF adalah bentuk gangguan gizi yang ditunjukkan dengan terjadinya dua masalah atau lebih pada saat dilakukan pengukuran antropometri (Mc Donald et al, 2013). Artinya ketika dilakukan pengukuran pada satu individu maka diperoleh interpretasi hasil dengan masalah kombinasi. Kombinasi ini dapat berupa: pendek - gemuk, pendek kurus, gizi kurang - pendek, gizi kurang kurus, dan lain sebagainya. Permasalahan seperti ini lebih kompleks jika dibandingkan dengan individu yang hanya bermasalah pada satu indeks antropometri.

Hasil analisis univariat menunjukkan bahwa sebanyak $23,2 \%$ balita mengalami CIAF, dengan dua ataupun tiga variasi masalah. Hanya $53,6 \%$ balita di Kota Bukittinggi yang memiliki status gizi normal. Juga dapat dilihat bahwa sebagian besarnya tidak mengonsumsi makanan yang beragam. Secara ringkas dapat dilihat pada tabel 2.

Dalam penelitian ini terdapat empat kategori makanan yang diamati terkait dengan keragaman makanan:

1. Keragaman konsumsi makanan pokok, jenis makanan yang dinilai adalah: nasi, mie, kentang, singkong, roti dan jagung

2. Keragaman konsumsi makanan sumber protein, jenis makanan yang dinilai adalah: ikan, telur, tahu dan tempe

3. Keragaman konsumsi sayur dan buah, jenis sayur dan buah yang dinilai adalah: kangkung, tauge, wortel, jeruk, pisang dan papaya
4. Keragaman konsumsi makanan pendukung pertumbuhan, jenis makanan yang dinilai adalah: susu bubuk dan susu cair/kental

Tabel 2

Hasil analisis univariat

\begin{tabular}{lcc}
\hline \multicolumn{1}{c}{ Variabel } & N & \% \\
\hline Kejadian CIAF & $\mathbf{6 3}$ & $\mathbf{2 3 , 6}$ \\
Ya & 53 & 19,9 \\
$\quad$ - Dua masalah & 10 & 3,7 \\
$\quad$ - Tiga masalah & $\mathbf{2 0 4}$ & $\mathbf{7 6 , 4}$ \\
Tidak & 62 & 23,2 \\
$\quad$ - Satu masalah & 142 & 53,2 \\
$\quad$ - Normal & 267 & 100 \\
\hline Jumlah & & \\
\hline Keragaman Makanan & & \\
1. Makanan Pokok & 132 & 49,4 \\
$\quad$ - Ya & 135 & 50,6 \\
$\quad$ - Tidak & & \\
2. Sumber Protein & 119 & 44,6 \\
$\quad$ - Ya & 148 & 55,4 \\
$\quad$ - Tidak & & \\
3. Sayur dan Buah & 127 & 47,6 \\
$\quad$ - Ya & 140 & 52,4 \\
$\quad$ - Tidak & & \\
4. Pendukung Pertumbuhan & 122 & 45,7 \\
$\quad$ - Ya & 145 & 54,3 \\
\hline - Tidak & 267 & 100 \\
\hline Jumlah - & & \\
\hline
\end{tabular}

Makanan pokok (sumber karbohidrat) yang banyak dikonsumsi anak selain nasi adalah kentang dan roti. Sedangkan sumber protein yang digemari anak adalah ikan telur dan tahu. Sayur dan buah yang paling disukai oleh anak adalah tauge dan pisang. Jenis susu yang banyak diminati anak adalah susu bubuk.

Berdasarkan informasi pada tabel 3, dapat diketahui konsumsi makanan pokok merupakan satu - satunya variabel yang berhubungan signifikan dengan kejadian CIAF pada anak ( $\mathrm{p}$ value $=0,034$ ). Analisis lebih lanjut menunjukkan bahwa anak dengan konsumsi makanan pokok beragam terlindungi dari kejadian CIAF sebanyakdua kali dibandingkan dengan anak yang konsumsi makanan pokoknya tidak beragam $(\mathrm{OR}=0,5)$. 
Tabel 3

Hasil Analisis Bivariat

\begin{tabular}{|c|c|c|c|c|c|c|c|c|}
\hline \multirow{3}{*}{$\begin{array}{c}\text { Keragaman } \\
\text { Makanan }\end{array}$} & \multicolumn{4}{|c|}{ CIAF } & \multirow{2}{*}{\multicolumn{2}{|c|}{ Total }} & \multirow[t]{3}{*}{$\mathrm{p}$ value } & \multirow[t]{3}{*}{ OR } \\
\hline & \multicolumn{2}{|c|}{$\mathrm{Ya}$} & \multicolumn{2}{|c|}{ Tidak } & & & & \\
\hline & $\mathrm{n}$ & $\%$ & $\mathrm{n}$ & $\%$ & $\mathrm{n}$ & $\%$ & & \\
\hline \multicolumn{9}{|l|}{$\begin{array}{l}\text { Makanan } \\
\text { pokok }\end{array}$} \\
\hline - Ya & 39 & 29,5 & 93 & 70,5 & 132 & 100 & 0,034 & 0,516 \\
\hline - Tidak & 24 & 17,8 & 111 & 82,2 & 135 & 100 & & \\
\hline \multicolumn{9}{|l|}{$\begin{array}{l}\text { Sumber } \\
\text { protein }\end{array}$} \\
\hline$-\quad Y a$ & 32 & 26,9 & 87 & 73,1 & 119 & 100 & 0,321 & - \\
\hline - $\quad$ Tidak & 31 & 20,9 & 117 & 79,1 & 148 & 100 & & \\
\hline \multirow{2}{*}{\multicolumn{9}{|c|}{$\begin{array}{l}\text { Sayur dan } \\
\text { buah }\end{array}$}} \\
\hline - Ya & 25 & 19,7 & 102 & 80,3 & 127 & 100 & & - \\
\hline - $\quad$ Tidak & 38 & 27,1 & 102 & 72,9 & 140 & 100 & & \\
\hline \multicolumn{9}{|l|}{$\begin{array}{l}\text { Pendukung } \\
\text { pertumbuhan }\end{array}$} \\
\hline$-\quad Y a$ & 32 & 26,2 & 90 & 73,8 & 122 & 100 & 0,432 & - \\
\hline - Tidak & 31 & 21,4 & 114 & 78,6 & 145 & 100 & & \\
\hline
\end{tabular}

Di Indonesia angka gabungan semua bentuk kasus CIAF adalah 51,4\% (Riskesdas, 2013). Lebih rendah dibandingkan angka tersebut, Kota Bukittinggi berada pada angka 23,6\%. Bentuk kasus paling banyak adalah pendek - gizi kurang yaitu 45,3\% dari seluruh kejadian CIAF.

Anak yang mengalami CIAF sebagian besar berusia di bawah tiga tahun dan berjenis kelamin laki - laki. Mereka umumnya anak pertama atau kedua didalam keluarga. Ibu mereka rata rata berusia diatas 30 tahun (paling muda 24 tahun dan paling tua 44 tahun). Walaupun berpendidikan tinggi (menamatkan SLTA) mereka memilih untuk tidak bekerja. Anak yang mengalami tiga masalah sekaligus sebagian besar (70\%) merupakan penderita gizi buruk.

Gupta dkk melakukan penelitian pada 100 orang anak balita di Kota Delhi, India pada tahun 2017. Mereka menemukan bahwa sebagian besar anak menderita CIAF (62\%). Angka tersebut jauh lebih tinggi dibandingkan dengan temuan dalam penelitian ini. Fenomena yang serupa adalah sebagian besar kasus terjadi pada anak berusia dibawah tiga tahun
(Gupta et al, 2017). Hal ini juga ditemukan pada penelitian yang dilakukan oleh Kherde dkk di Nagpur, India pada tahun yang sama. Kejadian CIAF di wilayah tersebut hampir sama dengan hasil penelitian ini yaitu $23,26 \%$ (Kherde et al, 2018).

Banyaknya anak pendek - gizi kurang dan kurus - gizi kurang menunjukkan bahwa masalah gizi yang terjadi merupakan masalah gizi yang akut - kronis. Uniknya masalah kompleks ini justru banyak ditemukan pada anak anak yang memiliki ibu berpendidikan tinggi tetapi tidak produktif secara ekonomi (lebih banyak di rumah/ibu rumah tangga). Usia para ibu juga merupakan usia ideal untuk menjaga dan merawat anak. Hanya sebagian kecil anak yang menderita penyakit infeksi dalam kurun waktu tiga bulan terakhir. Oleh karena itu, faktor konsumsi dan pola asuh diduga menjadi bagian penting dalam munculnya kasus ini.

Kebiasaan makan dan hidup yang sehat harus dimiliki sejak dini karena hal ini akan mempengaruhi kebiasaan hidup di masa yang akan datang. Belajar mencoba makanan baru, lebih menyukai makanan sehat dan pola makan yang sehat 
merupakan tahapan penting pada perkembangan anak. Kurang gizi pada masa ini akan berakibat kepada gangguan kognisi dan kemampuan anak dalam mengeksplorasi lingkungannya. Hal ini dapat dicegah dan dikurangi melalui gizi seimbang dan dukungan lingkungan (Brown, 2011).

Berdasarkan hasil penelitian hanya keragaman konsumsi makanan pokok yang berhubungan secara signifikan dengan kejadian CIAF pada anak ( $\mathrm{p}$ value $=0,034)$. Selanjutnya ditemukan nilai OR sebesar 0,52 artinya anak dengan konsumsi makanan pokok beragam terlindungi dari kejadian CIAF sebesar dua kali jika dibandingkan dengan anak yang konsumsi makanan pokoknya tidak beragam.

Hasil penelitian ini sejalan dengan penelitian Fentahun dkk di Ethiopia pada tahun 2016. Mereka menemukan bahwa konsumsi makanan beragam berhubungan signifikan dengan kejadian CIAF pada anak. Anak dengan tingkat keragaman konsumsi makanan yang rendah berisiko tiga kali lebih besar mengalami CIAF dibandingkan dengan anak yang konsumsi makanan hariannya beragam (Fentahun et al, 2016).

Para ibu selain memberikan nasi sebagai makanan sehari - hari juga seringkali memberikan kentang sebagai variasi tambahan bagi anak mereka. Selain itu, anak - anak juga menyukai roti (roti tawar/roti basah) sebagai makanan pelengkap (cemilan). Variasi dalam praktek pemberian makan ini menjadikan anak memiliki pengalaman yang menyenangkan ketika makan. Rasa bosan juga dapat dihindari karena anak juga disuguhi roti yang memiliki banyak varian rasa.

\section{SIMPULAN}

Kejadian malnutrisi sangat dipengaruhi oleh faktor konsumsi anak. Penelitian ini menemukan bahwa satu dari dua anak mengalami malnutrisi. Sebagian dari kasus tersebut adalah kegagalan antropometri gabungan (CIAF).Secara keseluruhan, anak tidak mengonsumsi makanan yang bervariasi (beragam), baik dari sumber karbohidrat, protein, sayur dan buah ataupun makanan pendukung pertumbuhan (susu).

Konsumsi makanan pokok merupakan hal yang krusial dalam menjaga status gizi anak tetap baik. Makanan pokok yang beragam dapat menghindarkan anak dari kejadian CIAF. Keragaman makanan pokok yang disajikan oleh ibu dapat meningkatkan nafsu makan anak sehingga asupan gizi sehari - hari dapat terpenuhi.

Kepada Dinas Kesehatan dan instansi kesehatan lainnya agar lebih giat dalam mengedukasi masyarakat (terutama ibu) untuk meningkatkan kualitas pemberian makan pada balita. Edukasi ini dapat dilakukan dengan mendemonstrasikan cara - cara pengolahan makanan yang inovatif. Hal ini dapat memicu para ibu untuk menyajikan makanan yang beragam bagi balitanya.

\section{UCAPAN TERIMA KASIH}

Penelitian ini terlaksana atas bantuan dana hibah penelitian dari Kementerian Riset dan Teknologi.

\section{REFERENSI}

Bappenas. (2012). Kerangka kebijakan gerakan sadar gizi dalam rangka 1000 Hari Pertama Kehidupan (1000 HPK). Jakarta

Brown, J.E. (2011). Nutrition through the life cycle. Wadsworth: Belmont USA

Dasgupta, A., Sanjaya, K.S., Pranita, T., Preeti, PS., Dhiraj, B,. Amitava, K,. \&Ishita, S. (2014). Composite index of Anthropometric Failure and Its Important Correlates: A Study Among Under - 5 Children In A Slum Kolkata, West Bengal, India. International Journal of 
Medical Science and Public Health, 2015 volume 4, issue 3

Detels, R., James, M.E., Robert, B,. \& Heizo, T. (2002). Oxford textbook of public health 4th edition. Oxford University Press.

Endris, N,. Henok, A., \& Lamessa, D. (2017). Prevalence of Malnutrition and Associated Factors Among Children In Rural Ethiopia. Biomed Researche International. https://doi.org/10.1155/2017/6587 $\underline{853}$

Fentahun, N., Tefera, B,. \& Carl, L. (2016). Determinants and Morbidities of Multiple Anthropometric Deficits in Southwest Rural Ethiopia. Nutrition Journal 32 (2016); 1243 $-1249$

Gibney, M.J., Susan, A.L,. Aedin, C., \& Hester, H.V. (2009). Intoduction to Human Nutrition Second Edition. Blackwell Publishing; United Kingdom

Gibson, R.S. (2005). Principles of Nutiritional Assessment. Oxford University Press: New York

Gupta, G., et al. (2017). Assessment of Undernutirition Among Chidren Below 5, Using Composite Index of Anthropometric Failure (CIAF). Indian Journal of Community Health 29 (2017); 108 - 113

International Food Policy Research Institute. (2014). Global Nutrition Report 2014: Action and Accountability to Accelerate the World's Progress on Nutrition. Wahington, DC

Kemenkes RI. (2015). Profil Kesehatan Indonesia 2015. Jakarta

Kemenkes RI. (2013). Laporan Riset Kesehatan Dasar tahun 2013. Badan Penelitian dan Pengembangan. Jakarta

Kemenkes RI. (2016). Situasi Balita Pendek. Pusat Data dan Informasi. Jakarta
Kepmenkes RI. (2010). Keputusan Meneteri Kesehatan Nomor 1995 tahun 2010 tentang Standar Antropometri Penilaian Status Gizi anak. Jakarta

Kherde, A., et al. (2018). Composite Index of Anthropometric Failure Among Under 5 Children Attending The Immnunoprophylaxis Clinic in Tertiary Care Hospital in Nagpur, Maharashtra, India. International Journal of Contemporary Pediatrics 5 (3); 888 - 892

Lewit, EM\&Nancy, K. (1997). Population-Based Growth Stunting. Children and Poverty vol 7 nomor 2.

McDonald, C.M., Ibironke, O., Seth, F., Wafaie, W.F., Donna, S., Laura, E.C., Robert, E.B., Majid, E., \& Goodarz, E. (2013). The Effect of Multiple Anthropometric Deficits On Child Mortality: Meta Analysis of Individual Data in 10 Prospective Studies From Developing Countries1-3. The American Journal of Clinical Nutrition 2013; 97; 896 - 901

Nandy, S., Michelle, I., David, G., Subramanian, S.V., \& George, D.S. (2005). Poverty, Child Undernutrition and Morbidity: New Evidence From India. Buletin of The World Health Organisation

Supariasa, I. D. N. (2002). Penilaian Status Gizi. EGC: Jakarta

UNDP. Sustainable Development Goals Booklet.

WHO. (2012). Knowledge Summary: Women's\&Children's Health, 18\# Nutrition. Geneva

Zhang, N., Lala, B., \& Tarani, C. (2016). Patterns and Determinants of Double Burden of Malnutrition Among Rural Children: Evidence From China. PLoS ONE 11(7): e0158119. doi: 10.1371/jounal.pone.0158119 